\title{
Heavy-mineral, mineral-chemical and zircon-age constraints on the provenance of Triassic sandstones from the Devon coast, southern Britain
}

\author{
Andrew Morton ${ }^{1,}$, , Mark W. Hounslow ${ }^{2}$, Dirk Frei $^{3}$ \\ ${ }^{1} \mathrm{HM}$ Research Associates, 2 Clive Road, Balsall Common, CV7 7DW, UK and CASP, University of Cambridge, \\ Cambridge CB3 0DH, United Kingdom; e-mail: heavyminerals@hotmail.co.uk \\ ${ }^{2}$ Centre for Environmental Magnetism and Palaeomagnetism, Lancaster Environment Centre, Lancaster University, \\ Lancaster LA1 4YW, United Kingdom \\ ${ }^{3}$ Central Analytical Facility, Stellenbosch University, Chamber of Mines Building, Matieland 7602, South Africa \\ *corresponding author
}

\begin{abstract}
An integrated heavy-mineral, mineral-chemical and zircon-dating study of the Triassic succession exposed on the south Devon coast, in the western part of the Wessex Basin, indicates derivation from a combination of granitic and metasedimentary lithologies of ages of mostly over $550 \mathrm{Ma}$. These sources were probably located at a relatively proximal location near the southern margin of the basin. Derivation from more distal sources in the Armorican Massif or local Variscan sources to the west appears unlikely in view of the scarcity of Permo-Carboniferous (Variscan-age) zircons. The Budleigh Salterton Pebble Bed Formation was derived from a different combination of source lithologies than the Otter Sandstone Formation, the former including staurolite-grade metasediments that were absent in the catchment area of the Otter Sandstone. The Devon coast succession has provenance characteristics that differ from equivalent sandstones further east in the Wessex Basin, and from sandstones in the East Irish Sea Basin to the north. These differences indicate that sediment supply patterns to the linked Triassic basin systems in southern Britain are complex, involving multiple distinct sub-catchment areas, and that heavy-mineral studies have considerable potential for unravelling these sub-catchment area sources.
\end{abstract}

Key words: heavy minerals, zircon, provenance, Triassic, Devon

\section{Introduction}

Triassic sediments in the southern UK were deposited in a series of linked basins, ranging from the Wessex Basin in the south, a number of basins in the English Midlands (Worcester, Stafford, Needwood, Knowle and Cheshire basins), to the East Irish Sea Basin and East Midlands Shelf in the north (Fig. 1). The Triassic sediments deposited in these basins can be broadly subdivided into the Sherwood Sandstone Group, which is of Early-Middle Triassic
(Olenekian-Anisian) age, overlain by the Mercia Mudstone Group, which is of Middle-Late Triassic (Anisian-Rhaetian) age (Hounslow \& Ruffell, 2006). Most of the succession has a redbed facies, deposited in a semi-arid climate with an annual summer monsoon, in a range of environments (ephemeral fluvial, aeolian and playa lacustrine) controlled by a complex interplay of climate and tectonics (Ruffell \& Shelton, 1999; McKie \& Williams, 2009; Preto et al., 2010). 


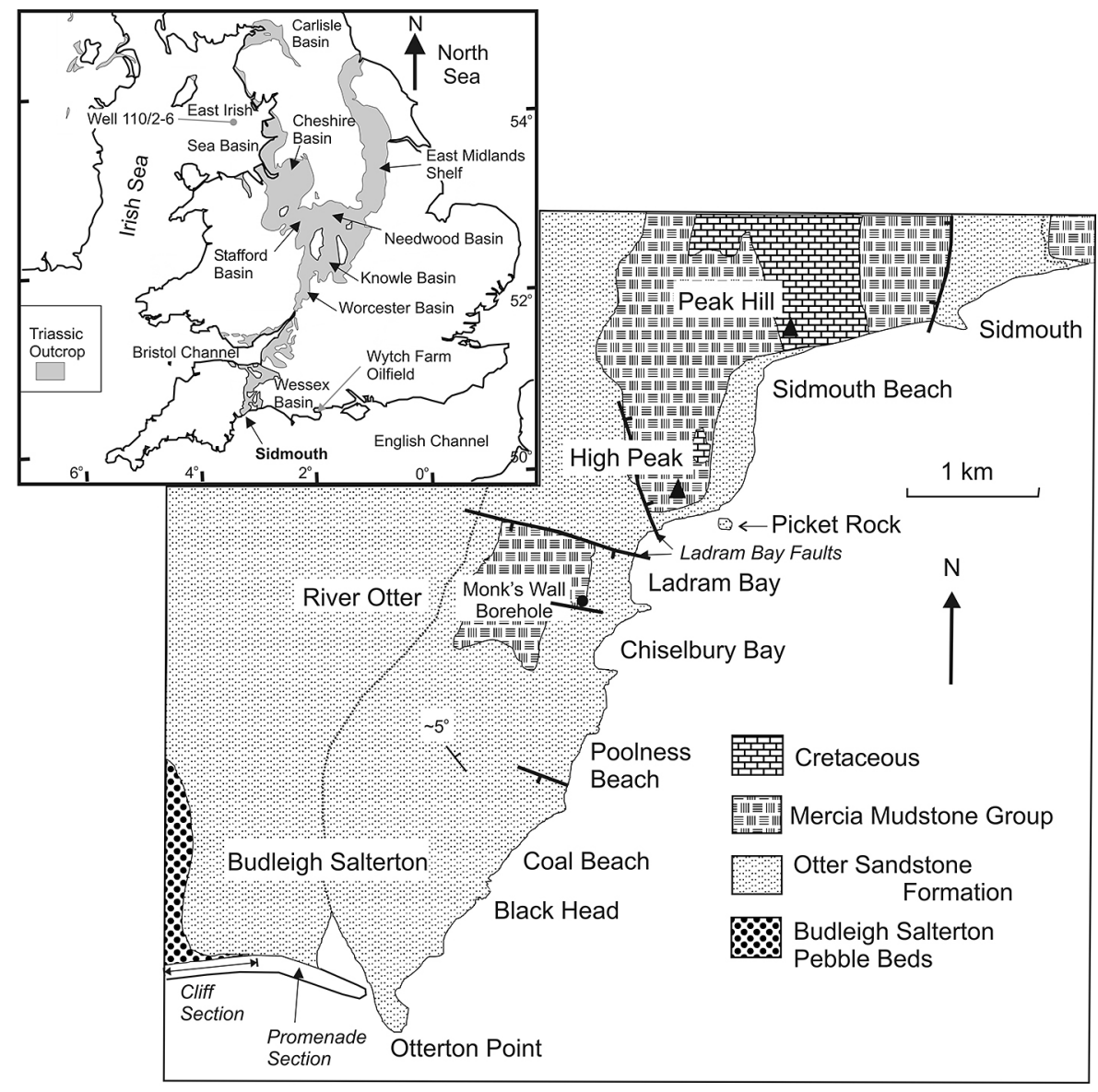

Fig. 1. Location of the Sherwood Sandstone Group outcrop on the Devon coast, southern UK, with inset showing the Wessex Basin in its regional context with the other Triassic outcrops of southern Britain. The inset map also shows the locations of the Wytch Farm oilfield (central Wessex Basin) and well 110/2-6 (East Irish Sea Ba$\sin )$. Adapted from Hounslow \& McIntosh (2003).

Deposition in these linked basins is believed to have been dominated by a large axial fluvial drainage system, termed the 'Budleighensis River' (Wills, 1956), which flowed from south to north and drained the Variscan mountains of northern France. Evidence for this comes from a variety of data, including clast compositions, palaeocurrents, detrital-mica ages, and $\mathrm{Pb}$-isotope compositions in feldspar.

Clasts in the conglomeratic lower part of the Sherwood Sandstone Group in the Wessex Basin (the Budleigh Salterton Pebble Beds Formation) include quartzites with an exotic Ordovician and Devonian brachiopod fauna similar to that found in Brittany and Normandy (Audley-Charles, 1970; Cocks, 1993, and references therein). The conglomeratic sediments at the base of the Sherwood Sandstone Group further north (Kidderminster Formation, Chester Pebble Beds) are also reported to contain fossiliferous quartzites of Armorican type (Audley-Charles, 1970, and references therein), together with igneous pebbles that have affinities with rocks of SW England (Campbell-Smith, 1963), and clasts from more proximal sources (Wills, 1970).

Palaeocurrent data from the Budleigh Salterton Pebble Beds Formation indicate a palaeocurrent toward the north and north-east (Smith \& Edwards, 1991), with a northward-directed palaeocurrent also recorded in the Sherwood Sandstone Group of the Cheshire Basin (Thompson, 1970; Steel \& Thompson 1983). This northward palaeocurrent appears to extend north even as far as the Cumbrian coast, on the NW margin of the East Irish Sea Basin (Jones \& Ambrose, 1994).

K-Ar-isotopic analyses of bulk detrital muscovite and biotite separates from the Sherwood Sandstone Group of the Cheshire Basin indicate that the source area contained micas ranging in age from 280 to $300 \mathrm{Ma}$ (Fitch et al., 1966), requiring that the mica provenance lay to the south, within the Variscan uplands. $\mathrm{Pb}$-isotopic data from K-feldspars in the Sherwood Sandstone Group in the Wessex and East 
Irish Sea Basins show that similar grain populations are present, and that their compositions can be matched with granites of Neoproterozoic-Cambrian (Cadomian) granites and Late Carboniferous-Permian (Variscan) granites in northern France, the French Massif Central, the Pyrenees and the Cornubian area of SW Britain (Tyrrell et al., 2012).

The Sherwood Sandstone Group of the Wessex Basin was the subject of some of the earliest heavy-mineral provenance studies ever undertaken in the UK (Thomas, 1902, 1909). Despite this long history, comparatively little modern quantitative heavy-mineral data have been collected on the Sherwood Sandstone Group from the linked basin system in order to test the 'Budleighensis River' concept. Morton \& Hallsworth (1994) showed that the Sherwood Sandstone Group in the Wytch Farm oilfield (central part of the Wessex Basin: Fig. 1) has distinctly different heavy-mineral provenance characteristics to that in the East Irish Sea Ba$\sin$. The Sherwood Sandstone in the latter basin was subsequently studied in detail by Mange et al. (1999), who argued that there was significant local input from a variety of areas bordering the basin, including the Welsh-Brabant Massif, the Ramsey-Whitehaven Ridge, the Isle of Man, and the Leinster Massif of Ireland. Mange et al. (1999) also noted the existence of abundant polycyclic detritus in the Sherwood Sandstone Group of the East Irish Sea Basin, implying widespread recycling from older sediments and metasediments. The heavy-mineral evidence for local input in the East Irish Sea Basin (Mange et al., 1999) would account for the differences in mineralogy between the Wytch Farm area and the East Irish Sea Basin recognised by Morton \& Hallsworth (1994). Subsequent studies of heavy-mineral assemblages in the Sherwood Sandstone Group of the Cheshire Basin (Jones et al., 2000) showed that these also differ from those found in the Wytch Farm area, but are more comparable with those in the East Irish Sea Basin.

Although some quantitative heavy-mineral data are available from the Wytch Farm succession in the central part of the Wessex Basin (Morton \& Hallsworth, 1994), equivalent data are not available from the outcrop sections of the Sherwood Sandstone Group in Devon, in the western part of the basin (Fig. 1). Apart from the pioneering work on this area in the very early part of the last century (Thomas, $1902,1909)$, the only data are general information on heavy-mineral abundances that were used in order to calibrate a chemostratigraphic study of the Otter Sandstone Formation by Svendsen \& Hartley (2002), and similar information on a small number of samples collected as part of a regional provenance study by Jeans et al. (1993). In view of the importance of this section as a key point in evaluating the role of the 'Budleighensis River' system (Tyrrell et al., 2012), an integrated heavy-mineral study, combining determination of provenance-sensitive heavy-mineral ratios, mineral-chemical data on tourmaline and garnet, and detrital-zircon ages, has been undertaken in order to constrain the provenance of the sandstones and conglomerates in the succession and to provide a framework for comparison with equivalent sandstones in the linked basins to the north.

\section{The Sherwood Sandstone Group of Devon}

In the Wessex Basin, the Sherwood Sandstone Group is divided into a lower conglomeratic unit, the Budleigh Salterton Pebble Beds Formation (BSPBF), and an overlying sandstone-dominated unit, the Otter Sandstone Formation (OSF) (Fig. 2). The boundary between the BSPBF and the underlying Aylesbeare Mudstone Group (Early Triassic) is an unconformity (Holloway et al., 1989), which is most clearly apparent from seismic surveys and well data farther east in the Wessex Basin (Butler, 1998). The unconformity between the BSPBF and the OSF is considered to be equivalent to the Hardegsen Unconformity in the Germanic Basin (Holloway et al., 1989; Butler, 1998). However, magnetostratigraphy suggests that the base of the OSF in the outcrops of south Devon corresponds to a slightly younger level (Hounslow \& McIntosh, 2003). Late Permian red-beds underlying the Aylesbeare Mudstone Group in the western part of the Wessex Basin clearly document the unroofing of the Permian 


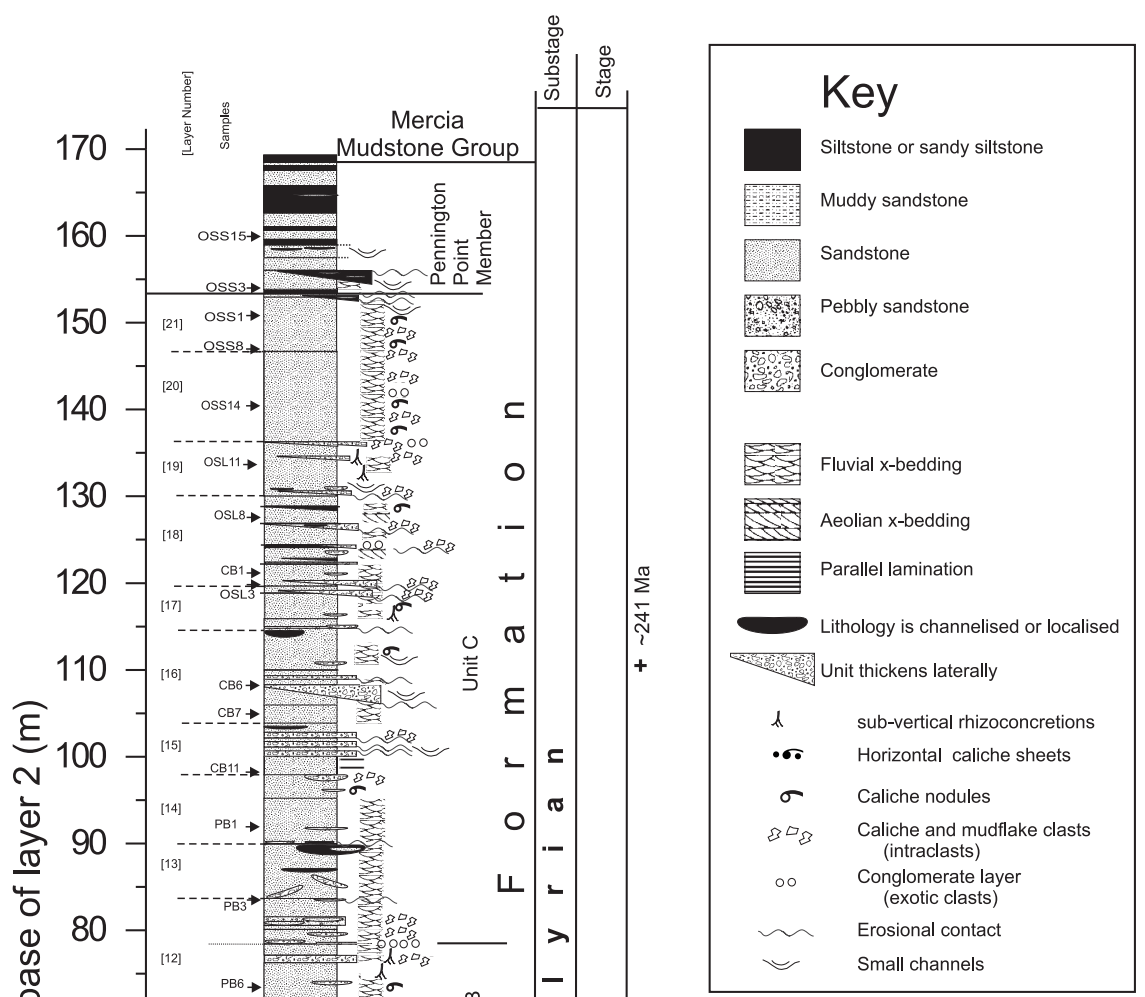

Fig. 2. Composite stratigraphic section of the Sherwood Sandstone Group outcrop on the Devon Coast (adapted from Hounslow \& McIntosh, 2003), showing the locations of samples analysed during the heavy-mineral provenance study.

(Variscan) granites of SW England in the Early and Middle Permian (Edwards et al., 1997).

The BSPBF is composed of orthoconglomerates and subordinate sandstones, representing the deposits of a braidplain or wet alluvial fan (Smith, 1990; Smith \& Edwards 1991). On the basis of magnetostratigraphy, Hounslow \& McIntosh (2003) suggested that the BSPBF represents only a short interval of the Early Triassic. The quartzite clasts within the BSPBF contain an exotic Ordovician and Devonian brachiopod fauna probably derived from Brittany and Normandy (Cocks, 1993), together with tourmalinised hornfels and quartz-porphyry clasts that have affinities with rocks of SW England (Campbell-Smith, 1963). When the BSPBF is traced northwards, there are changes in mineralogy and clast composition that indicate supply from upland areas of Cornubia. Thomas (1902) noted a gradual northward decrease in the abundance of staurolite, together with an increase in abundance of minerals interpreted as derived from the west, such as cassiterite and blue tourmaline. In the northerly part of the BSPBF outcrop, the abundance of locally-derived Devonian sandstone and limestone clasts increases (Edmonds \& Williams, 1985; Smith \& Edwards, 1991). 
A horizon of wind-faceted pebbles (ventifacts) is regionally important at the top of the BSPBF (Leonard et al., 1982; Smith \& Edwards 1991). In the coastal section of southern Devon, this horizon is associated with a desert palaeosol (Fig. 2) estimated to have formed over a time-span of 50,000-100,000 years (Wright et al., 1991). This major hiatus represents the unconformity surface beneath the OSF. In the central and eastern parts of the Wessex Basin, the unconformity surface locally truncates faults in the underlying succession (Butler, 1998). Holloway et al. (1989) suggested that there was erosion at this time, in order to explain the absence of conglomerates below the OSF in the central parts of the Wessex Basin, although Smith \& Edwards (1991) argued that this could equally well be due to non-deposition or to lateral facies changes.

The OSF, which forms the majority of the Sherwood Sandstone Group within the Wessex Basin, largely consists of stacked fluvial channel sandstones, with minor mudstones and aeolian sandstones. At outcrop in southern Devon (Fig. 2), the age of the OSF is believed to range from the latest Early Triassic to near the Anisian/ Ladinian boundary (Hounslow \& McIntosh, 2003). Farther east in the Wessex Basin, around the Wytch Farm oil field (Fig. 1), seismic evidence suggests that the upper part of the Sherwood Sandstone Group passes into the Mercia Mudstone Group, indicating that the upper boundary of the Sherwood Sandstone Group is probably diachronous (Butler, 1998).

In the coastal outcrop of southern Devon (Fig. 1), the OSF has been divided into four units, A, B, C and the Pennington Point Member (Hounslow \& McIntosh 2003; Gallois, 2004). These loosely define an overall fining-upward succession, a feature that is also seen in the OSF of the Wytch Farm area (Lott \& Strong 1982; Holloway et al., 1989; McKie et al. 1998; Svendsen \& Hartley, 2001, 2002). In the coastal outcrops, the oldest part of the OSF (Unit A) is a $\sim 20 \mathrm{~m}$ thick heterogeneous unit consisting of aeolian sandstones at the base overlain by fluvial channel sandstones that lack calcretes (Fig. 2). The overlying Unit B is characterised by multi-storey stacked channel sandstones, with a paucity of lacustrine or floodplain mud- stones. In-situ calcretes are common in Unit B, in the form of both vertical rhizoconcretions and horizontal sheets (Purvis \& Wright, 1991). The basal lags of the channel sandstones include abundant reworked calcrete and mudstone clasts.

Unit $C$ of the OSF has more abundant mudstone- and sandstone-filled channels, with lesser amounts of calcrete (both in-situ and reworked), representing a higher-sinuosity river system (Svendsen \& Hartley, 2001). Minor aeolian sandstones also occur in the upper part of the OSF at Wytch Farm (McKie et al., 1998; Edwards, 1999). The Pennington Point Member, which represents the uppermost unit of the OSF at outcrop (Fig. 2), is a succession of fluvial channel and sheetflood sandstones interbedded with numerous red mudstones. The sandstones in the Pennington Point Member lack reworked calcrete, and may be heavily channelised, similar in character to the uppermost units of the OSF at Wytch Farm, where they are interpreted as lacustrine (McKie et al., 1998).

Palaeocurrent directions have been measured on the sections at Chiselbury Bay and Ladram Bay (Unit C, beds 15-19 in Fig. 2). These indicate a shift from northwesterly- to northeasterly-directed palaeocurrents with time (Lorsong \& Atkinson, 1995).

\section{Analytical methods}

\subsection{Conventional (petrographic) analysis}

Rock samples were gently disaggregated by use of a pestle and mortar, avoiding grinding action. Chemicals were not used in order to avoid the possibility of modifying assemblages in the laboratory. Following disaggregation, the samples were immersed in water and cleaned by ultrasonic probe to remove and disperse any clay adhering to grain surfaces. The samples were then washed through a $63 \mu \mathrm{m}$ sieve and resubjected to ultrasonic treatment until no more clay passed into suspension. At this stage, the samples were wetsieved through the 125 and $63 \mu \mathrm{m}$ sieves, and the resulting $>125 \mu \mathrm{m}$ and $63-125 \mu \mathrm{m}$ fractions 


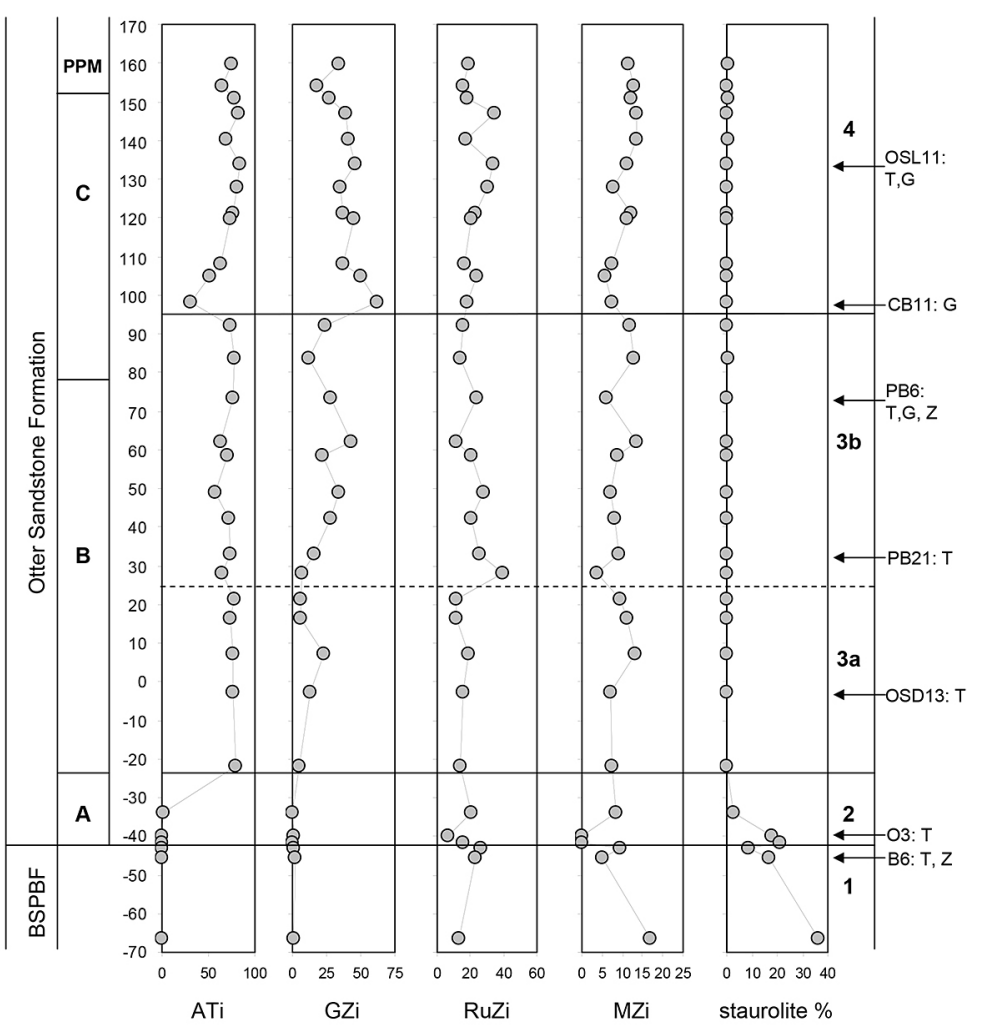

Fig. 3. Stratigraphic variations in key heavy-mineral parameters in the Sherwood Sandstone Group on the Devon coast. A, B and C are lithostratigraphic subdivisions, as shown in Figure 2. 1, 2, 3 and 4 are heavy-mineral zones (HM1-4) as discussed in the present contribution. $\mathrm{ATi}=$ apatite:tourmaline index; $\mathrm{GZi}=$ garnet:zircon index; RuZi = rutile:zircon index; $\mathrm{MZi}=$ monazite:zircon index (all as defined by Morton \& Hallsworth, 1994).

Samples chosen for tourmaline geochemical analysis, garnet geochemical analysis and zircon dating are indicated by $T, G$ and $Z$, respectively. were dried in an oven at $80^{\circ} \mathrm{C}$. The $63-125 \mu \mathrm{m}$ fraction was placed in bromoform with a measured specific gravity of 2.8. Heavy minerals were allowed to separate under gravity, with frequent stirring to ensure complete separation. The heavy-mineral residues were mounted under Canada balsam (cf. Marcinkowski \& Mycielska-Dowgiałło, 2013) for optical study using a polarising microscope. Where possible, a split was retained for mineral-chemical and zircon-dating studies.

The heavy-mineral proportions were estimated by counting 200 non-opaque detrital grains using the ribbon method described by Galehouse (1971). Identification was made on the basis of optical properties, as described for grain mounts by Mange \& Maurer (1992). A qualitative assessment was also made of other components, such as diagenetic minerals, opaques and mica. Determination of provenance-sensitive mineral ratios (Morton \& Hallsworth, 1994) was ideally made on the basis of a 200-grain count per mineral pair, although this was not always possible because of the scarcity of some of the mineral phases. Stratigraphic variations in key mineral parameters are shown in Fig. 3. Light minerals and opaque heavy minerals, although sometimes of interest for provenance studies (see Ludwikowska-Kędzia, 2013; Woronko et al., 2013), have not been investigated.

\subsection{Garnet and tourmaline geochemistry by electron microprobe analysis (EMPA)}

Samples for garnet and tourmaline geochemistry analysis by EMPA were selected on the basis of the results of the conventional optical analysis. The selected grains were analysed at Aberdeen University using a Link Systems AN10000 energy-dispersive X-ray analyser attached to a Cambridge Instruments Microscan $\mathrm{V}$ electron microprobe. The quality of each result was monitored to ensure that the stoichiometrically-determined formulae corresponded to ideal garnet and tourmaline compositions.

Garnet compositions are expressed in terms of the relative abundance of the $\mathrm{Mg}, \mathrm{Fe}^{2+}, \mathrm{Ca}$ and Mn end members. The compositions of garnet assemblages are shown using ternary diagrams (Fig. 4) with relative proportions of $\mathrm{Fe}^{2+}+\mathrm{Mn}$, $\mathrm{Mg}$ and $\mathrm{Ca}$ in the garnet molecule as poles, calculated assuming that all $\mathrm{Fe}$ is present as $\mathrm{Fe}^{2+}$. 


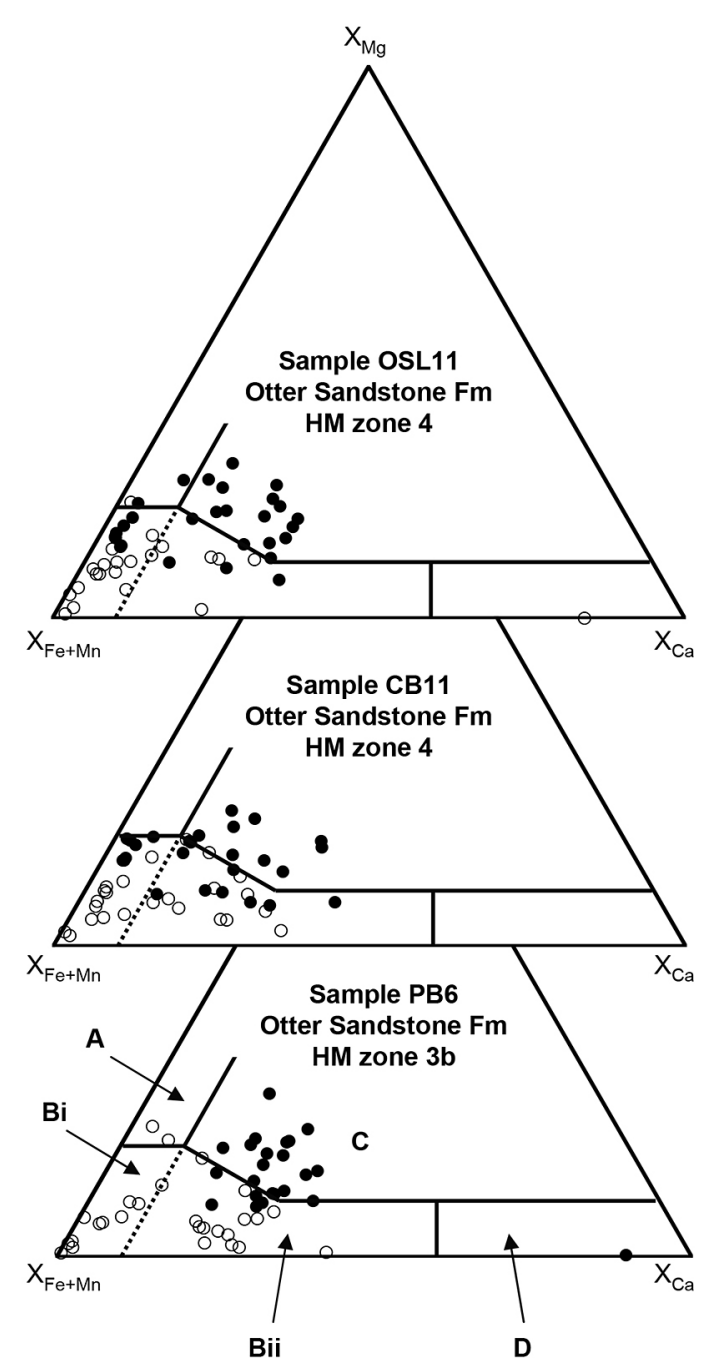

Fig. 4. Garnet compositions in the Sherwood Sandstone Group of the Devon coast. The stratigraphic locations of the samples are shown in Figure 3.

$\mathrm{X}_{\mathrm{Fe}^{\prime}} \mathrm{X}_{\mathrm{Mg}^{\prime}}, \mathrm{X}_{\mathrm{Ca}^{\prime}}, \mathrm{X}_{\mathrm{Mn}}=$ proportions of $\mathrm{Fe}, \mathrm{Mg}$, Ca and $\mathrm{Mn}$ in the garnet molecule. All Fe calculated as $\mathrm{Fe}^{2+}$; $\bullet=$ $\mathrm{X}_{\mathrm{Mn}}<5 \% ; \circ=\mathrm{X}_{\mathrm{Mn}}>5 \%$. Fields A, Bi, Bii, C and D are from Mange \& Morton (2007).

The tourmaline compositions are expressed in terms of the relative abundances of $\mathrm{Al}, \mathrm{Fe}$ and $\mathrm{Mg}$, and are plotted on the provenance-discriminant $\mathrm{Al}-\mathrm{Al}_{50} \mathrm{Mg}_{50}-\mathrm{Al}_{50}-\mathrm{Fe}(\text { tot })_{50}$ ternary diagram (Fig. 5) devised by Henry \& Guidotti (1985).

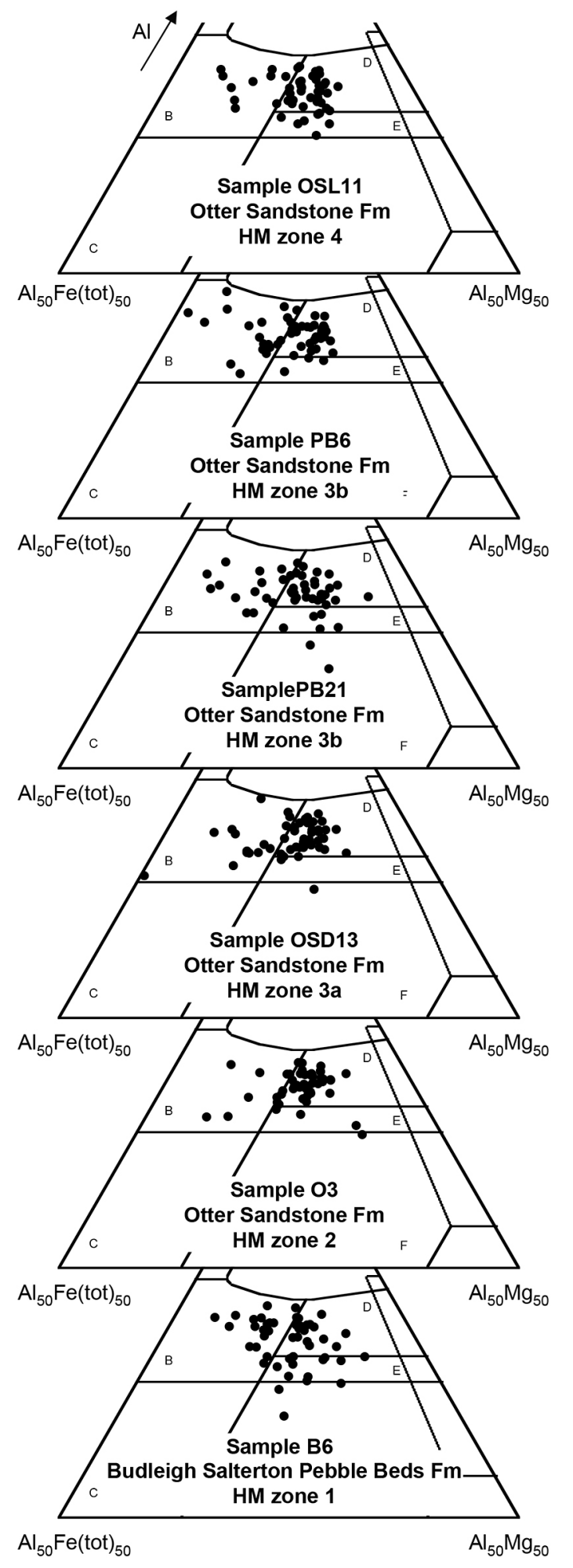

Fig. 5. Tourmaline compositions in the Sherwood Sandstone Group of the Devon coast, plotted on the provenance-discriminant Al-Mg-Fe diagram of Henry \& Guidotti (1985). The stratigraphic locations of the samples are shown in Figure 3.

Field A = Li-rich granitoids, pegmatites, aplites; Field B = Li-poor granitoids, pegmatites, aplites; Field C = hydrothermally-altered granitic rocks; Field $\mathrm{D}=$ metapelites, metapsammites (aluminous); Field $\mathrm{E}=$ metapelites and metapsammites (Al-poor); Field $\mathrm{F}=\mathrm{Fe}^{3+}$-rich quartz-tourmaline rocks, calc-silicates, metapelites. 


\subsection{Zircon dating}

Zircons were separated from the bulk samples using conventional heavy-liquid and magnetic-separation methods. The final separation step was made by hand-picking individual zircon grains from the heavy and non-mag- netic fraction using an optical microscope. The individual zircon grains were mounted on double-sided, transparent adhesive tape and subsequently embedded in 1-inch-diameter circular epoxy mounts for polishing. In order to study their internal structure, backscatter electron (BSE) images of all analysed zircon

Table 1. LA-SF-ICP-MS U-Th-Pb dating methodology employed at CAF, Stellenbosch University, South Africa.

\begin{tabular}{|c|c|}
\hline \multicolumn{2}{|r|}{ Laboratory \& sample preparation } \\
\hline laboratory name & Central Analytical Facility, Stellenbosch University \\
\hline sample type / mineral & detrital zircons \\
\hline sample preparation & conventional mineral separation, 1 inch resin mount, $1 \mu \mathrm{m}$ polish to finish \\
\hline imaging & CL, LEO $1430 \mathrm{VP}, 10 \mathrm{nA}, 15 \mathrm{~mm}$ working distance \\
\hline \multicolumn{2}{|r|}{ Laser ablation system } \\
\hline make, model \& type & ESI/New Wave Research, UP213, Nd:YAG \\
\hline ablation cell \& volume & Custom build low volume cell, volume approx. $3 \mathrm{~cm}^{3}$ \\
\hline laser wavelength & $213 \mathrm{~nm}$ \\
\hline pulse width & $3 \mathrm{~ns}$ \\
\hline fluence & $2.5 \mathrm{~J} / \mathrm{cm}^{-2}$ \\
\hline repetition rate & $10 \mathrm{~Hz}$ \\
\hline spot size & $30 \mu \mathrm{m}$ \\
\hline sampling mode / pattern & $30 \mu \mathrm{m}$ single spot analyses \\
\hline carrier gas & $100 \% \mathrm{He}$, Ar make-up gas combined using a T-connector close to sample cell \\
\hline $\begin{array}{l}\text { pre-ablation laser warm-up } \\
\text { (background collection) }\end{array}$ & $40 \mathrm{~s}$ \\
\hline ablation duration & $20 \mathrm{~s}$ \\
\hline wash-out delay & $30 \mathrm{~s}$ \\
\hline cell carrier gas flow & $0.31 /$ minute $\mathrm{He}$ \\
\hline \multicolumn{2}{|r|}{ ICP-MS instrument } \\
\hline make, model \& type & Thermo Finnigan Element2 single collector HR-SF-ICP-MS \\
\hline sample introduction & via conventional tubing \\
\hline RF power & $1100 \mathrm{~W}$ \\
\hline make-up gas flow & $1.01 /$ minute Ar \\
\hline detection system & single collector secondary electron multiplier \\
\hline masses measured & $202,204,206,207,208,232,233,235,238$ \\
\hline integration time per peak & $4 \mathrm{~ms}$ \\
\hline total integration time per reading & approx. $1 \mathrm{~s}$ \\
\hline sensitivity & $20000 \mathrm{cps} / \mathrm{ppm} \mathrm{Pb}$ \\
\hline dead time & $16 \mathrm{~ns}$ \\
\hline \multicolumn{2}{|r|}{ Data processing } \\
\hline gas blank & 40 s on-peak \\
\hline calibration strategy & $\begin{array}{l}\text { GJ-1 used as primary reference material, Plešovice \& M127 used as secondary } \\
\text { reference material (quality control) }\end{array}$ \\
\hline reference material info & $\begin{array}{l}\text { M127 (Nasdala et al., 2008; Mattinson, 2010); Plešovice (Slama et al., 2008); GJ-1 } \\
\text { (Jackson et al., 2004) }\end{array}$ \\
\hline $\begin{array}{l}\text { data processing package used / } \\
\text { correction for LIEF }\end{array}$ & $\begin{array}{l}\text { in-house spreadsheet data processing using intercept method for laser-induced } \\
\text { elemental fractionation (LIEF) correction }\end{array}$ \\
\hline mass discrimination & $\begin{array}{l}\text { standard-sample bracketing with } 207 \mathrm{~Pb} / 206 \mathrm{~Pb} \text { and } 206 \mathrm{~Pb} / 238 \mathrm{U} \text { normalised to } \\
\text { reference material GJ-1 }\end{array}$ \\
\hline $\begin{array}{l}\text { common-Pb correction, composi- } \\
\text { tion and uncertainty }\end{array}$ & $\begin{array}{l}\text { 204-method, Stacey \& Kramers (1975) composition at the projected age of the min- } \\
\text { eral, } 5 \% \text { uncertainty assigned }\end{array}$ \\
\hline uncertainty level \& propagation & $\begin{array}{l}\text { ages are quoted at } 2 \sigma \text { absolute, propagation is by quadratic addition; reproduc- } \\
\text { ibility and age uncertainty of reference material and common-Pb composition } \\
\text { uncertainty are propagated }\end{array}$ \\
\hline quality control / validation & $\begin{array}{l}\text { Plešovice: } W \text { td ave } 206 \mathrm{~Pb} / 238 \mathrm{U} \text { age }=337 \pm 4(2 \mathrm{SD}, \mathrm{MSWD}=0.2) \\
\text { M127: } \mathrm{Wtd} \text { ave } 206 \mathrm{~Pb} / 238 \mathrm{U} \text { age }=520 \pm 5(2 \mathrm{SD}, \mathrm{MSWD}=0.8)\end{array}$ \\
\hline Other information & detailed method description reported by Frei \& Gerdes (2009) \\
\hline
\end{tabular}


grains were obtained using a Philips XL 40 scanning electron microscope.

$\mathrm{U}-\mathrm{Pb}$ ages were obtained at the Central Analytical Facility, Stellenbosch University, by laser ablation - single collector - magnetic sectorfield - inductively coupled plasma - mass spectrometry (LA-SF-ICP-MS) employing a Thermo Finnigan Element2 mass spectrometer coupled to a NewWave UP213 laser ablation system. All age data presented here were obtained by single-spot analyses with a spot diameter of $30 \mu \mathrm{m}$ and a crater depth of approx. $15-20 \mu \mathrm{m}$, corresponding to an ablated zircon mass of approx. 150-200 ng. The methods employed for analysis and data processing have been described in detail by Gerdes \& Zeh (2006) and Frei \& Gerdes (2009). For quality control, the Plešovice (Sláma et al., 2008) and M127 (Nasdala et al. 2008; Mattinson 2010) zircon reference materials were analysed, and the results were consistently in excellent agreement with the published ID-TIMS ages. Full analytical details and the results for all quality control materials analysed are reported in Table 1.

The calculation of concordia ages and plotting of concordia diagrams were performed using Isoplot/Ex 3.0 (Ludwig 2003). Stacked histogram - relative probability plots of the zircon-age populations have been plotted using AgeDisplay (Sircombe, 2004).

\section{Heavy-mineral assemblages}

The heavy-mineral assemblages in the BSP$\mathrm{BF}$ and OSF comprise eleven non-opaque and non-micaceous detrital components (anatase, apatite, cassiterite, dumortierite, epidote, garnet, monazite, staurolite, titanite, tourmaline and zircon). Of these, cassiterite, dumortierite, epidote and titanite are present sporadically and in very minor amounts $(<0.5 \%)$. The range of minerals present is closely comparable to that recorded by Thomas (1902, 1909), who also recognised other minerals in very minor amounts (actinolite, kyanite, sillimanite, serpentine, topaz), but failed to identify apatite, owing to the use of hydrochloric acid during sample preparation. Jeans et al. (1993) identified common apatite, garnet, rutile, tourmaline, staurolite and zircon, together with minor titanite. Svendsen \& Hartley (2002) recognised apatite, garnet, monazite, titanite, tourmaline

Table 2. Comparison of the main detrital heavy-mineral abundances in the Otter Sandstone Formation as determined in the present study with those determined by Jeans et al. (1993) and Svendsen \& Hartley (2002). Abundance ranges are not shown for the Svendsen \& Hartley data because their analyses included non-detrital components (carbonate and Fe-oxides). Data collected during this study are from the 63-125 $\mu \mathrm{m}$ size range, whereas those of Jeans et al. (1993) and Svendsen \& Hartley (2002) are from 64-250 $\mu \mathrm{m}$ and 63-210 $\mu \mathrm{m}$, respectively

\begin{tabular}{lcccccccc} 
& At & Ap & Gt & Mo & Ru & St & To & Zr \\
\hline & \multicolumn{7}{c}{ Otter Sandstone Fm. } \\
range (this study)* & $2.5-13.5$ & $11.0-64.0$ & $<0.5-27.5$ & $<0.5-5.5$ & $0.5-7.0$ & $0.0-0.5$ & $9.5-31.0$ & $5.0-32.5$ \\
mean (this study)* & 7.1 & 44.2 & 7.9 & 1.9 & 4.0 & 0.1 & 17.8 & 16.9 \\
range (Jeans et al., 1993) & n.i. & $26-50$ & $3-14$ & n.i. & $2-6$ & 0 & $22-43$ & $11-35$ \\
mean (Jeans et al., 1993) & n.i. & 35 & 10 & n.i. & 4 & 0 & 30 & 22 \\
mean (Svendsen \& Hartley, 2002)** & n.i. & 37.1 & 9.6 & 2.9 & n.i. & n.i. & 29.1 & 12.5 \\
& \multicolumn{1}{c}{ Budleigh Salterton Pebble Beds Fm. } & & & \\
range (this study) & $5.5-15.5$ & 0.0 & $<0.5-0.5$ & $1.0-4.0$ & $4.0-6.5$ & $8.5-36.0$ & $28.0-48.0$ & $18.0-22.0$ \\
mean (this study) & 10.8 & 0.0 & 0.3 & 2.7 & 5.5 & 20.5 & 40.5 & 19.7 \\
range (Jeans et al., 1993) & n.i. & $0-1$ & $0-1$ & n.i. & $1-4$ & $9-27$ & $45-71$ & $2-40$ \\
mean (Jeans et al., 1993) & n.i. & 1 & $<1$ & n.i. & 2 & 19 & 60 & 18 \\
\hline
\end{tabular}

At: anatase; Ap: apatite; Gt: garnet; Mo: monazite; Ru: rutile; St: staurolite; Zr: zircon;

n.i.: not identified.

*excludes basal Otter Sandstone (heavy-mineral zone 2), which has a mineralogy that is more comparable to that of the Budleigh Salterton Pebble Beds.

**mean values recalculated excluding carbonate and Fe-oxides. 
and zircon, together with Fe-Ti oxides. A comparison of the range and mean values of the main heavy-mineral components found in this study and in those of Jeans et al. (1993) and Svendsen \& Hartley (2002) is shown in Table 2. Variations in mineral parameters enable subdivision of the succession into four heavy-mineral zones, with zone 1 corresponding to the BSPBF and zones 2-4 to the OSF (Fig. 3).

The mineralogical constitution of the BSPBF (heavy-mineral zone 1) determined during this study is closely comparable to that of Jeans et al. (1993), the main differences being that Jeans et al. (1993) recorded higher tourmaline abundances, and that the ranges of both tourmaline and zircon are wider in the Jeans et al. (1993) data set. These differences are probably attributable to the fact that Jeans et al. (1993) analysed a wider grain-size range $(64-250 \mu \mathrm{m})$ than the current study $(63-125 \mu \mathrm{m})$. The OSF mineralogy determined during the present study is also closely comparable with the earlier data of Jeans et al. (1993) and Svendsen \& Hartley (2002), the main discrepancies being partly attributable to differences in the grainsize ranges that were analysed and partly due to mineral categorisation: for example, Svendsen \& Hartley (2002) did not specifically identify rutile, but included this mineral in the wider 'Fe-Ti oxides' category.

The data confirm the results of previous studies by Thomas $(1902,1909)$ and Jeans et al. (1993) for a distinct difference in mineralogy between the BSPBF and OSF, the main manifestation of the contrast being the abundance of staurolite in the BSPBF and its virtually complete absence higher in the stratigraphy (Fig. 3). The other main difference is the absence of apatite (measured as ATi, the apatite:tourmaline index) in the BSPBF and its relative abundance in the OSF (Fig. 3). Garnet (measured as GZi, the garnet:zircon index) is also absent in the BSPBF, but occurs in minor to moderate amounts in the OSF (Fig. 3). This major change in mineralogy does not take place at the boundary between the two formations, but slightly higher up, at the boundary between Unit A and Unit B in the lower part of the OSF (between heavy-mineral zones 2 and 3).
The heavy-mineral assemblages in the OSF are comparatively uniform, but there are some minor variations that can be used to subdivide the succession. The most significant change takes place near the base of Unit C, where there is a distinct but short-lived reduction in ATi accompanied by an increase of GZi. This event has been used to mark the boundary between heavy-mineral zones 3 and 4 (Fig. 3). In addition, there are relatively subtle upward increase in GZi and RuZi that have been used to subdivide zone 3 into a lower subzone $3 a$ and a higher subzone $3 \mathrm{~b}$. It is likely that the boundary between zones 3 and 4 is coincident with the boundary between the upper and lower OSF as identified in the Devon coast section by Svendsen \& Hartley (2002), which takes place some 50-60 $\mathrm{m}$ below the top of the formation (their Fig. 7), probably around the base of 'layer $15^{\prime}$ as shown in Figure 2.

\section{Mineral chemistry}

Major-element mineral-chemical analyses of tourmaline and garnet have been undertaken on a limited number of samples (Figs 4 and 5), in order to provide additional information on the nature of the sediment sources. Tourmaline data have been acquired from the entire succession, but garnet analyses have been undertaken only for the upper part (heavy-mineral zones 3 and 4), owing to the scarcity of garnet in the BSPBF and lowest part of the OSF (zones 1 and 2).

The three garnet populations are closely comparable to one another, each having three main compositional groups (Fig. 4). A relatively large number of garnets are Mn-rich and $\mathrm{Mg}$ - and Ca-poor, and therefore plot in Field Bi as defined by Mange \& Morton (2007). Garnets with these compositions are typically derived from granitic sources. The second group comprises high- $\mathrm{Mg}$, high-Ca garnets (Field C of Mange \& Morton, 2007), compositions that are generally associated with high-grade metamafic rocks. The third group falls in Field Bii (low-Mg, variable $\mathrm{Ca}$ ), and was probably derived from amphibolite-facies metasediments, although garnets of this composition are less 
Fig. 6. Stratigraphic variations in compositions of detrital tourmaline populations in the Sherwood Sandstone Group of the Devon coast. Tourmaline types B, D, E and $\mathrm{F}$ are as defined in Figure 5.
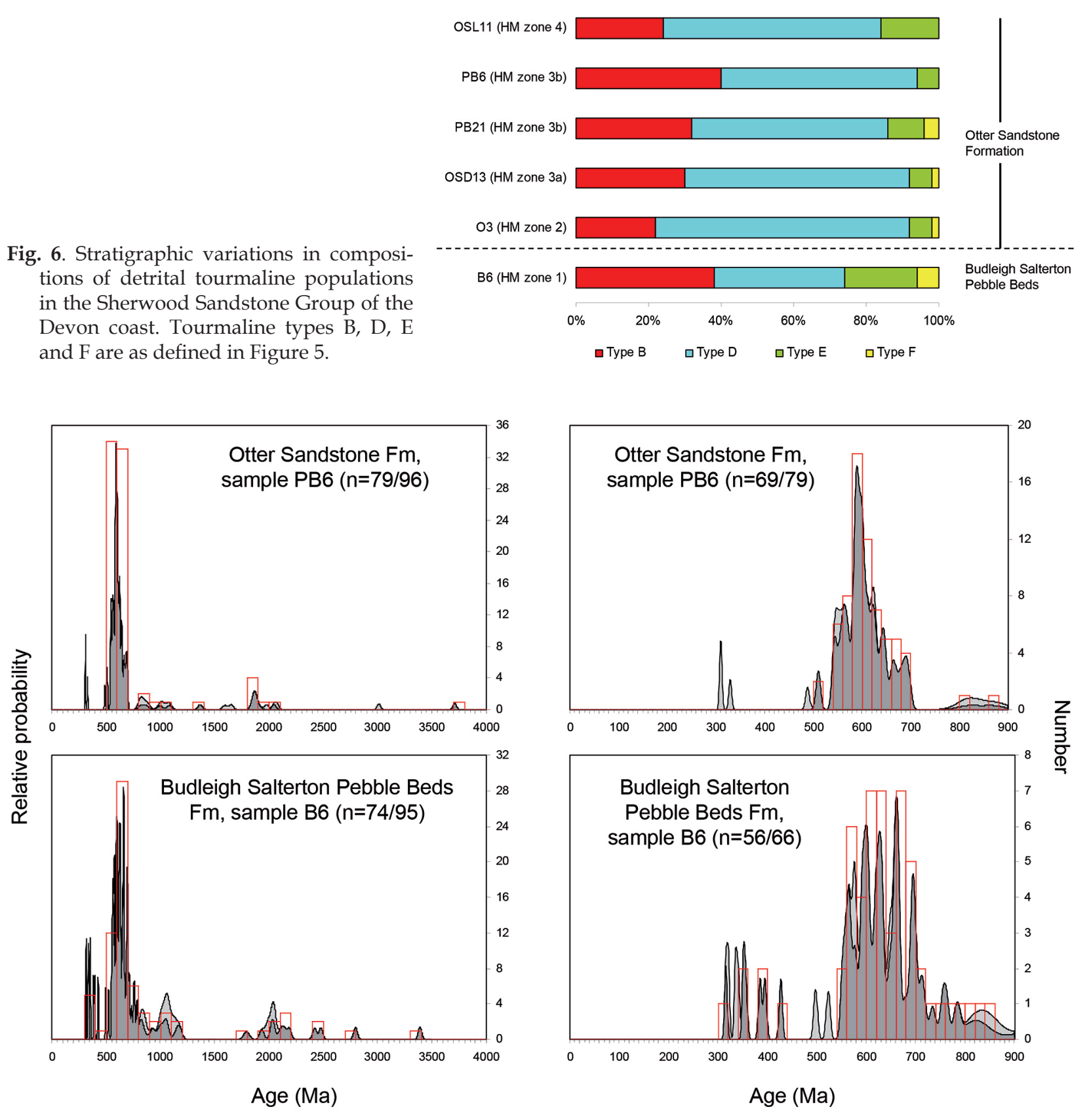

Fig. 7. Detrital-zircon ages in the Budleigh Salterton Pebble Beds Formation and Otter Sandstone Formation, displayed as combined histogram - relative probability diagrams generated using AgeDisplay (Sircombe, 2004). $n$ denotes the number of zircons with $90-110 \%$ concordance and the total number of zircon analyses.

source-diagnostic than the other two groups. There does not appear to be any stratigraphic trend in garnet composition, despite the overall increase in abundance of garnet with time (increasing GZi).

Most of the tourmalines have compositions that correspond to Field D of Henry \& Guidotti (1985), with variable proportions that fall in Field B (Fig. 5). Field D tourmalines form 36$70 \%$ of the populations, compared with $22-40 \%$ in Field B (Fig. 6). Most of the samples have only minor representations of Fields $\mathrm{E}$ and $\mathrm{F}$, but the sample from the BSPBF has higher proportions of these tourmalines than does the OSF $(20 \%$ and $6 \%$, respectively, compared with $6-16 \%$ and $0-4 \%$ ). These data indicate that the tourmalines were derived principally from Alrich metasediments (Field D) with subordinate input from Li-poor granitoids (Field B) and generally minor input from $\mathrm{Al}$-poor metased- 
iments (Fields E and F). The BSPBF appears to have a tourmaline population that slightly differs from the OSF (Fig. 6), with lower proportions falling in Field $D$ and relatively large numbers in Fields B, E and F. This difference confirms the heavy-mineral evidence for a difference in provenance of the BSPBF and OSF.

\section{Detrital-zircon ages}

Zircon-age data have been acquired on two samples, one from the BSPBF (sample B6, heavy-mineral zone 1) and one from the OSF (sample PB6, zone 3b), in order to provide geochronological constraints on the provenance of these two formations. The age spectra are broadly similar, both having dominant Late Neoproterozoic groups in the $\sim 540-700 \mathrm{Ma}$ range, with subordinate older Precambrian zircons extending as far back as $3710 \mathrm{Ma}$ (Fig. 7). The older Precambrian includes representation of earlier Neoproterozoic zircons ( $700-860$ $\mathrm{Ma}$ ), a small group at $\sim 1000-1200 \mathrm{Ma}$, and another small group at $\sim 1800-2100 \mathrm{Ma}$, together with occasional zircons scattered through the earlier Palaeoproterozoic and Archaean. These older Precambrian zircons form a higher proportion of the BSPBF spectrum than of the OSF, but in both cases the abundance of zircons older than $700 \mathrm{Ma}$ is low. The BSPBF and OSF also differ in that the Late Neoproterozoic in the BSPBF is represented by a broad zircon group, with distinct peaks at $\sim 560 \mathrm{Ma}, \sim 610 \mathrm{Ma}, \sim 630$ $\mathrm{Ma}, \sim 660 \mathrm{Ma}$ and $\sim 690 \mathrm{Ma}$, whereas the Late Neoproterozoic zircons in the OSF form essentially a group of similar ages, peaking in the 580-600 Ma range. Although these differences are relatively minor, they nevertheless provide further evidence for a change in sediment source between the two units.

The most surprising feature of both spectra is the scarcity of younger, Variscan-age, zircons. The BSPBF spectrum contains four zircons with $90-110 \%$ concordance that correspond to the Late Devonian to Carboniferous (316 Ma, $351 \mathrm{Ma}, 356 \mathrm{Ma}$ and $385 \mathrm{Ma}$ ), but grains of this age are absent in the OSF samples, apart from 3 zircons with $>10 \%$ discordance (Fig. 7 ).

\section{Provenance of the Devon coast Triassic succession}

The presence of distinct changes in mineralogy within the Devon coast Triassic succession indicates that the sediment provenance evolved with time. The BSBPF (heavy-mineral zone 1) is characterised by low apatite (low ATi), low garnet (low GZi), and relatively high staurolite contents. The overlying basal part of the OSF (zone 2) is generally similar to the BSB$\mathrm{PF}$, but the overlying parts of the OSF (zones 3-4) have a contrasting mineralogy, with moderate to high $\mathrm{ATi}$, low to moderate $\mathrm{GZi}$, and a scarcity of staurolite. There are also differences in the tourmaline geochemistry within the succession, and although zircon-age spectra in the BSPBF and OSF are broadly comparable, they show some differences in detail. In addition, there are changes within the OSF, with an overall upward increase in relative abundance of garnet (higher GZi) and rutile (higher RuZi).

The lack of apatite and garnet in the BSPBF strongly suggests that the sediment has undergone extensive weathering (cf. Van Loon \& Mange, 2007), since both minerals are unstable under such conditions (Morton, 2012). Furthermore, the presence of abundant staurolite indicates the source included moderate-grade metapelitic rocks, and such rocks would also be expected to supply garnet. The weathering could have occurred during alluvial storage prior to final deposition; alternatively, it could have taken place at the depositional site, or it could have been due to a combination of the two. The presence of a well-established desert palaeosol at the top of the BSPBF, estimated to have formed over a time span of 50,000-100,000 years (Wright et al., 1991), and the highly permeable nature of the BSPBF, suggests that the weathering took place at the depositional site, at least in part. In combination with the tourmaline data, which indicate the presence of a range of metapelitic rocks in association with Li-poor granitoids, the source region can be reconstructed as comprising metasediments at least up to staurolite grade (supplying staurolite, rutile and some of the tourmaline), in combination with granites that supplied zircon and the remaining tourmaline. Apatite and garnet 
are also likely to have been supplied to the transport system, but have been lost through weathering at the depositional site, possibly as well as during periods of alluvial storage prior to final deposition.

The basal part of the OSF (heavy-mineral zone A) has similar characteristics to the BSP$\mathrm{BF}$, with low ATi and GZi together with high staurolite abundances, although the latter decrease towards the top. These features suggest that the sediment was largely recycled from the BSPBF during the aeolian depositional phase that immediately followed the BSPBF and the palaeosol (Fig. 2). The decrease in staurolite towards the top may herald the appearance of typical fluvially-derived OSF detritus that characterises the rest of the formation.

The majority of the OSF (UM units 3 and 4) is typified by heavy-mineral assemblages that lack staurolite and have consistently moderate to high ATi. The sandstones show an evolution in certain features with time, notably increasing GZi and RuZi. The assemblage has a predominantly granitic aspect, on the basis of the high apatite and zircon contents, the presence of tourmalines of Li-poor granitoid origin, and garnets rich in $\mathrm{Fe}$ and $\mathrm{Mn}$. Metasediments must also have been involved, in order to account for the remainder of the tourmaline population and for the high-Ca, low-Mg garnets, but unlike the BSBPF, these did not contain staurolite. The garnet data also suggest the presence of metamafic rocks in the source area. The overall increase in garnet and rutile with time suggests that granitic sources became less important, although they appear to have remained dominant throughout. The short-lived reduction in ATi at the base of heavy-mineral zone 4 is interpreted as representing a phase of increased weathering, possibly due to a reduction or temporary cessation in sediment supply. It is noteworthy that this event is coincident with a significant increase in GZi, possibly indicating a reorganisation of the sediment supply system.

The zircon-age data perhaps provide the most important constraints on the location of the source regions for both the BSPBF and OSF. Given that their sources lay to the south on the basis of a variety of other provenance indicators, most notably the presence of fossiliferous pebbles of Armorican aspect, the dominance of the late Neoproterozoic group indicates that the Cadomian basement (as found, for example, in the Channel Islands and northern France) was the main source. The Cadomian granitoid basement rocks are believed to have formed in two phases from $\sim 615 \mathrm{Ma}$ to $\sim 540 \mathrm{Ma}$ (Samson et al., 2005). U-Pb zircon dating of the Cadomian granitoids of La Hague, Normandy, indicates two phases of magmatism, an earlier one between $620 \mathrm{Ma}$ and $608 \mathrm{Ma}$ and a later one between $583 \mathrm{Ma}$ and $572 \mathrm{Ma}$ (Samson et al., 2005). Granitoids and rhyolites from Jersey have been dated by zircon U-Pb as 580-583 Ma (Miller et al., 2001). The dominant peak in the OSF ( 580-600 Ma) therefore corresponds to the range of Cadomian granitoids in northern Armorica. These granitoids are also likely to have supplied some of the zircons in the BSPBF, but the older Neoproterozoic zircons probably represent derivation from Brioverian (Neoproterozoic) metasediments, since these contain Neoproterozoic zircons dating back to $\sim 760 \mathrm{Ma}$ (Samson et al., 2005).

The small groups of zircon dated as $\sim 1800$ $2100 \mathrm{Ma}$ in both samples could correspond to the Palaeoproterozoic basement of northern Armorica (Calvez \& Vidal, 1978; Vidal et al., 1981; Guerrot \& Peucat, 1990; Samson \& D'Lemos, 1998; Inglis et al., 2004). In addition to Neoproterozoic zircons, the Brioverian metasediments contain Palaeoproterozoic and Archaean grains as old as 3.1 Ga (Miller et al., 2001; Sansom et al., 2005), and it is therefore likely that these also supplied sediment to the Devon coast during the mid-Triassic, especially given the evidence for the presence of metasedimentary detritus as well as granitic material. The origin of the late Mesoproterozoic to early Neoproterozoic group is less certain, since the Brioverian metasediments do not contain this group (Miller et al., 2001; Samson et al., 2005), and crystalline rocks of this age do not appear to be present in the Armorican Massif (Roach et al., 1990). However, such zircons are found as detrital components of sediments in other parts of the Armorican Massif (Catalán et al., 2004; Dinis et al., 2012), and recycling from 
pre-existing sediment is therefore considered their most likely origin.

Possibly the most important constraint on the location of the sources for the BSPBF and OSF is provided by the scarcity of Late Carboniferous to Early Permian zircons related to the Variscan orogenesis and associated magmatic activity. Variscan granites are widespread in the Armorican Massif of northern France and equivalent parts of the Variscan mountain belt in central Europe (Tischendorf et al., 1995; Brown \& Dallmeyer, 1996; Ballèvre, 2009; Tyrrell et al., 2012). These granites are known to have been available as a sediment source as early as the Late Carboniferous, on the basis of the presence of detrital zircons in Westphalian sandstones of the UK (Hallsworth et al., 2000; Morton et al., 2010), and on the basis of evidence for rapid exhumation of such granites in the Variscan mountain belt (Schulmann et al., 2002). The scarcity of Late Carboniferous and Early Permian zircons in the Devon coast succession suggests that the catchment area did not extend into regions of Armorica that include widespread Variscan granites, and therefore implies that the source was more proximal, probably in the English Channel and possibly extending into the Channel Islands, the La Hague peninsula and the northern Brittany coast, where Variscan granites are comparatively minor (Brun et al., 2001; Sansom et al., 2005). Furthermore, the Early Permian Dartmoor granite is only some $25 \mathrm{~km}$ away from the Devon outcrop, and is known to have been unroofed in the Late Permian since it supplied a significant amount of clastic detritus to the Permian Exeter Group that underlies the Early-Middle Triassic Sherwood Sandstone Group and Early Triassic Aylesbeare Mudstone Group (Edwards et al., 1997). Derivation from the Cornubian area immediately to the west therefore also seems unlikely.

\section{Implications regarding the 'Budleighensis River'}

The heavy-mineral data acquired from the Devon coast Triassic succession are consistent with sourcing from the south, as indicated by previous studies (especially the evidence from fossiliferous pebbles). The new data indicate that the source region had limited exposure of Late Carboniferous-Early Permian (Variscan) granites, and therefore must have been relatively proximal to the Wessex Basin, since such granites are widespread across most of Brittany apart from the northern coastal region. The source is therefore considered to have principally lain in the English Channel region, possibly extending into the Channel Isles, the La Hague peninsula and the northern Brittany coast. This evidence is consistent with the palaeogeographic reconstructions of Warrington \& Ivimey-Cook (1992), which suggest relatively proximal sourcing (Fig. 8). The absence of Early Permian zircons in the BSPBF and OSF indicates that the Cornubian massif to the west had ceased to supply clastics into the western Wessex Basin by the mid-Triassic, even though it supplied clastic material during the Permian (Edwards et al., 1997). It also appears that the unconformity that separates the Sherwood Sandstone and Aylesbeare Mudstone Groups was not associated with sufficient uplift to rework the underlying Permian, at least in the south Devon area.

The scarcity of Late Carboniferous-Early Permian (Variscan) zircons indicates that the Devon coast succession was not supplied by a large river system draining the Massif Central, Brittany, Normandy and possibly the Pyrenees (Tyrrell et al., 2012) (Fig. 8). However, it is possible that a large river system draining these regions (as envisaged by Tyrrell et al., 2012) was responsible for the Sherwood Sandstone Group further east in the Wessex Basin, since the differences in heavy-mineral ratio characteristics between the Wytch Farm oilfield and the Devon coast (Fig. 9) indicate that the two areas were fed from different sources. The provenance relationships between the Sherwood Sandstone Group of the Devon coast and that in the central and eastern parts of the Wessex Basin require further investigation, to expand the heavy-mineral database and to acquire mineral-chemical and zircon-age data. Further work is also needed to investigate the reasons behind the marked 
Fig. 8. Palaeogeographic reconstructions of the Sherwood Sandstone Group of southern Britain. Upper (Induan-Olenekinan) and middle (Anisian) diagrams have been adapted from Warrington \& IvimeyCook (1992). The lower diagram has been adapted from Tyrrell et al. (2012).

$\mathrm{IM}=$ Irish Massif; B\&C = Brittany and Cornwall granites; FMS = French Massif Central granites; $P Y=$ Pyrenees granites. Brown $=$ upland areas, yellow $=$ non-marine basins, blue $=$ marine basins, red $=$ granites.

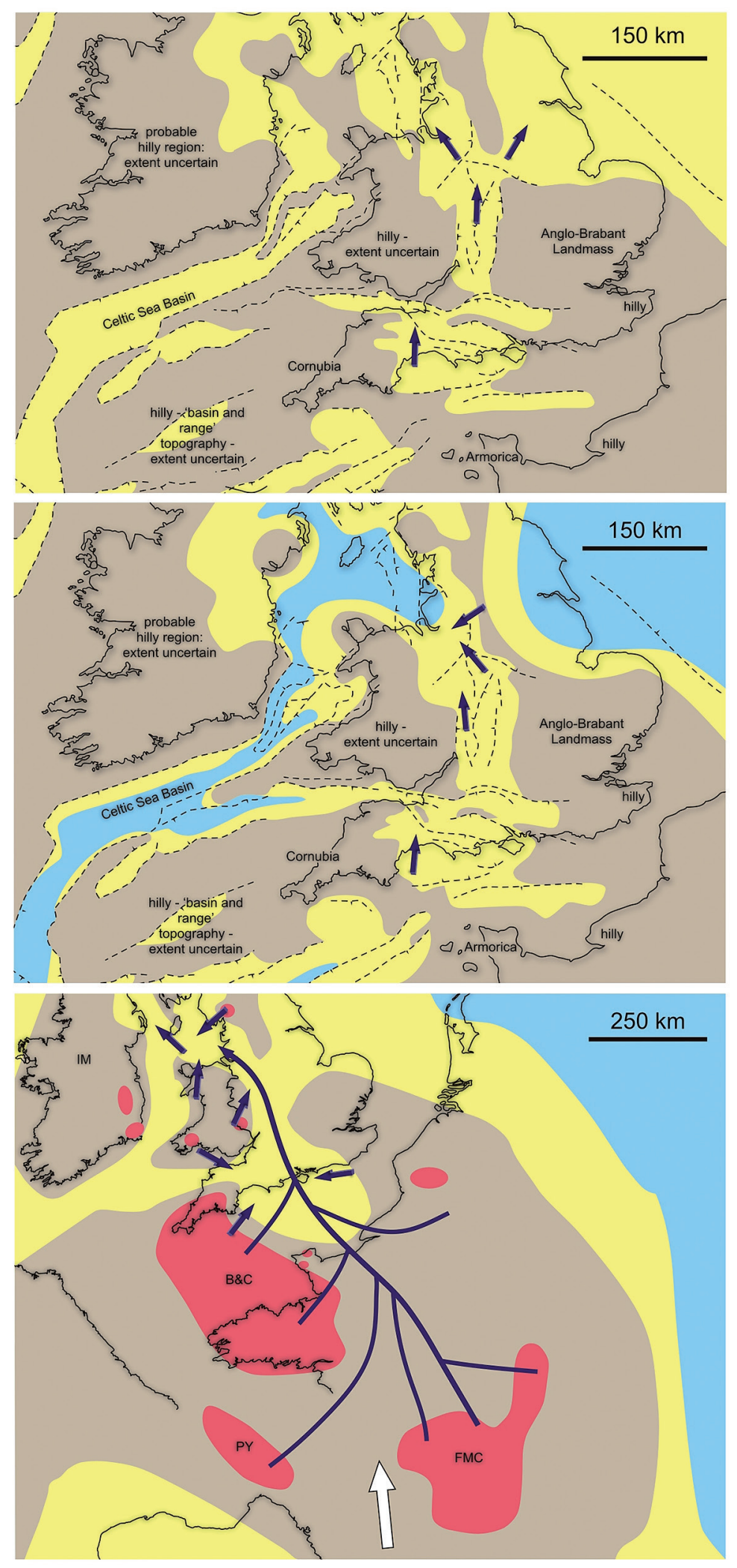

difference in heavy-mineral assemblages between the Wessex Basin and the East Irish Sea Basin, as illustrated by reductions in ATi (apa- tite:tourmaline) and MZi (monazite:zircon) between the southern and northern parts of the ‘Budleighensis River' system (Fig. 9). 


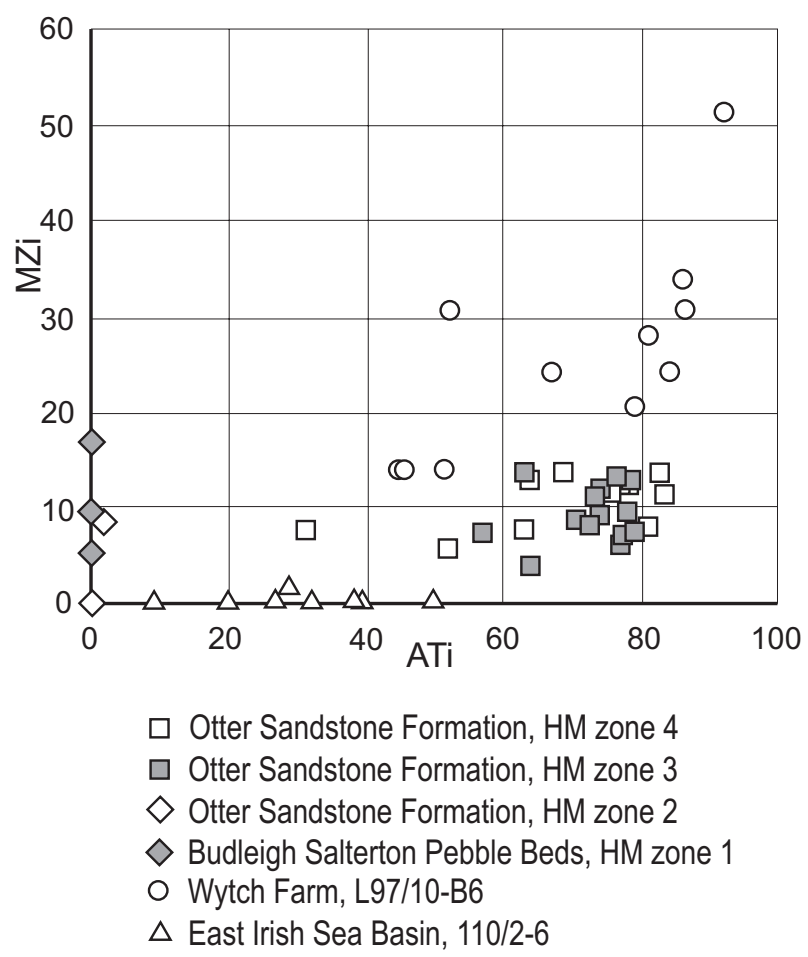

Fig. 9. Binary plot of the monazite:zircon index (MZi) and the apatite:tourmaline index (ATi) comparing the Sherwood Sandstone of the Devon coast, the Wytch Farm oilfield (central Wessex Basin) and well 110/2-6 (East Irish Sea Basin). The plot demonstrates the presence of lateral differences in provenance across the Wessex Basin and the markedly different character of the sandstones towards the northern extent of the 'Budleighensis River' system. Locations of Wytch Farm and well 110/2-6 are shown in Figure 1.

\section{Conclusions}

An integrated heavy-mineral, mineral-chemical and zircon-dating study of the Triassic succession exposed on the south Devon coast on the western margin of the Wessex Basin confirms derivation from the Armorican Massif to the south, but indicates that the catchment area was relatively small and did not extend southwards or westwards into zones where Variscan granites are widespread. The Devon coast succession has different characteristics to stratigraphically equivalent sandstones further east in the Wessex Basin, indicating that the 'Budleighensis River' system is complex, and comprises at least two different systems draining different parts of the Armorican Massif. Available data indicate that there are marked contrasts in mineralogy between the proximal (southern) part of the 'Budleighensis River' system and the distal (northern) region. Further heavy-mineral studies are required to investigate the causes of these mineralogical variations within the linked Triassic basins of southern Britain.

\section{References}

Audley-Charles, M.G., 1970. Triassic palaeogeography of the British Isles. Quarterly Journal of the Geological Society of London 126, 49-89.

Ballèvre, M., Bosse, V., Ducassou, C. \& Pitra, P., 2009. Palaeozoic history of the Armorican Massif: models for the tectonic evolution of the suture zones. Comptes Rendus de Géoscience 341, 174-201.

Brown, M. \& Dallmeyer, R.D., 1996. Rapid Variscan exhumation and the role of magma in core complex formation: southern Brittany metamorphic belt, France. Journal of Metamorphic Geology 14, 361-379.

Brun, J.P., Guennoc, P., Truffert, C., Vairon, J. \& The ARMOR Working Group of the GeoFrance 3-D Program, 2001. Cadomian tectonics in northern Brittany: a contribution of 3-D crustal-scale modelling. Tectonophysics 331, 229-246.

Butler, M., 1998. The geological history and the southern Wessex Basin - a review of new information from oil exploration. [In:] J.R. Underhill (Ed.): Development, evolution and petroleum geology of the Wessex Basin. Geological Society of London, Special Publication 133, 67-86.

Calvez, J.Y. \& Vidal, P., 1978. Two billion year old relicts in the Hercynian Belt of western Europe. Contributions to Mineralogy and Petrology 65, 395-399.

Campbell-Smith, W., 1963. Description of the igneous rocks represented among pebbles from the Bunter Pebble Beds of the Midlands of England. Bulletin of the British Museum of Natural History (Mineralogy) 2, 1-17.

Catalán, J.R.M., Fernández-Suárez, J., Jenner, G.A., Belousova, E. \& Montez, A.D., 2004. Provenance constraints from detrital zircon $\mathrm{U}-\mathrm{Pb}$ ages in the NW Iberian Massif: implications for Palaeozoic plate configuration and Variscan evolution. Journal of the Geological Society 161, 463-476.

Cocks, L.R.M., 1993. Triassic pebbles, derived fossils and the Ordovician to Devonian palaeogeography of Europe. Journal of the Geological Society 150, 219-226.

Dinis, P., Andersen, T., Machado, G. \& Guimarães, F., 2012. Detrital zircon U-Pb ages of a late-Variscan Carboniferous succession associated with the Porto-Tomar shear zone (West Portugal): provenance implications. Sedimentary Geology 273/274, 19-29.

Edmonds, E.A. \& Williams, B.J., 1985. Geology of the country around Taunton and the Quantock Hills - Memoir for 1:50,000 geological sheet 295 (England and Wales). British Geological Survey, HMSO, London.

Edwards, R.A., 1999. The Minehead district: a concise account of the geology - Memoir for 1:50,000 geological sheet 
278 and part of sheet 294 (England and Wales). British Geological Survey, HMSO, London.

Edwards, R.A., Warrington, G., Scrivener, R.C., Jones, N.S., Haslam, H.W. \& Ault, L., 1997. The Exeter Group, south Devon, England: a contribution to the early post-Variscan stratigraphy of northwest Europe. Geological Magazine 134, 177-197.

Fitch, F.J., Miller, J.A. \& Thompson, D.B., 1966. The palaeogeographic significance of isotopic age determinations on detrital micas from the Triassic of the Stockport-Macclesfield district, Cheshire, England. Palaeogeography, Palaeoclimatology, Palaeoecology 2, 281-312.

Frei, D. \& Gerdes, A., 2009. Precise and accurate in-situ $\mathrm{U}-\mathrm{Pb}$ dating of zircon with high sample throughput by automated LA-SF-ICP-MS. Chemical Geology 261, 261-270.

Galehouse, J.S., 1971. Point-counting. [In:] R.E. Carver (Ed.): Procedures in sedimentary petrology. Wiley-Interscience, New York, 385-407.

Gallois, R.W., 2004. The type section of the junction of the Otter Sandstone Formation and the Mercia Mudstone Group (mid Triassic) at Pennington Point, Sidmouth. Geoscience in south-west England 11, 51-58.

Gerdes, A. \& Zeh, A., 2006. Combined U-Pb and Hf isotope LA-(MC)-ICP-MS analyses of detrital zircons: comparison with SHRIMP and new constraints for the provenance and age of an Armorican metasediment in central Germany. Earth and Planetary Science Letters 249, 47-61.

Guerrot, C. \& Peucat, J.J., 1990. U-Pb geochronology of the Upper Proterozoic Cadomian orogeny in the northern Armorican Massif, France. [In:] D'Lemos, R.S., Strachan, R.A. \& Topley, C.C. (Eds): The Cadomian orogeny. Geological Society, London, Special Publications 51, 13-26.

Hallsworth, C.R., Morton, A.C., Claoué-Long, J. \& Fanning, C.M., 2000. Carboniferous sand provenance in the Pennine Basin, UK: constraints from heavy mineral and detrital zircon age data. Sedimentary Geology 137, 147-185.

Henry, D.J. \& Guidotti, C.V., 1985. Tourmaline as a petrogenetic indicator mineral: an example from the staurolite-grade metapelites of NW Maine. American Mineralogist 70, 1-15.

Holloway, S., Milodowski, A.E., Strong, G.E. \& Warrington, G., 1989. The Sherwood Sandstone Group of the Wessex Basin, southern England. Proceedings of the Geologists Association 100, 383-394.

Hounslow, M.W. \& Ruffell, A.H., 2006. Triassic: seasonal rivers, dusty deserts and saline lakes. [In:] P.J. Brenchley \& P.F. Rawson (Eds): Geology of England and Wales. Geological Society, London, 295-324.

Hounslow, M.W. \& McIntosh, G., 2003. Magnetostratigraphy of the Sherwood Sandstone Group (Lower and Middle Triassic), South Devon, UK: detailed correlation of the marine and non-marine Anisian. Palaeogeography, Palaeoclimatology, Palaeoecology 193, 325-348.

Inglis, J.D., Samson, S.D., D'Lemos, R.S. \& Hamilton, M., 2004. U-Pb geochronological constraints on the tec- tonothermal evolution of the Paleoproterozoic basement of Cadomia, La Hague, NW France. Precambrian Research 134, 293-315.

Jackson, S., Pearson, N., Griffin, W. \& Belousova, E., 2004. The application of laser ablation - inductively coupled plasma - mass spectrometry to in situ U-Pb zircon geochronology. Chemical Geology 211, 47-69.

Jeans, C.V., Reed, S.J.B. \& Xing, M., 1993. Heavy mineral stratigraphy in the UK Trias: western approaches, onshore England and the central North Sea. [In:] J.R. Parker (Ed.): Petroleum geology of Northwest Europe Proceedings of the 4th Conference. Geological Society, London, 609-624.

Jones, D.G., Morton, A.C., Leng, M.J., Haslam, H.W., Milodowski, A.E., Strong, G.E. \& Kemp, S.J., 2000. Provenance of the basin fill. [In:] J.A. Plant, D.G. Jones \& H.W. Haslam (Eds): The Cheshire Basin: basin evolution, fluid movement and mineral resources in a Permo-Trias rift setting. British Geological Survey, Keyworth, UK, 90-124.

Jones, N.S. \& Ambrose, K., 1994. Triassic sandy braidplain and aeolian sedimentation in the Sherwood Sandstone Group of the Sellafield area, west Cumbria. Proceedings of the Yorkshire Geological Society 50, 61-76.

Leonard, A.J., Moore, A.G. \& Selwood, B.E., 1982. Ventifacts from a deflation surface marking the top of the Budleigh Salterton Pebble Beds, east Devon. Proceedings of the Ussher Society 5, 333-339.

Lorsong, J.M. \& Atkinson, C.D., 1995. Sedimentology and stratigraphy of Lower Triassic alluvial deposits, East Devon coast. Excursion guide. Petroleum Group. Geological Society, London.

Lott, G.K. \& Strong, G.E., 1982. The petrology and petrography of the Sherwood Sandstone (?Middle Triassic) of the Winterborne Kingston Borehole, Dorset. Report of the Institute of Geological Sciences 81/3, 135-142.

Ludwig, K.R., 2003. Isoplot/Ex version 3: a geochronological toolkit for Microsoft Excel. Berkeley Geochronology Center, Special Publication, 4.

Ludwikowska-Kędzia, M., 2013. The composition of transparent heavy minerals in Quaternary sediments of the Kielce-Łagów valley (Holy Cross Mountains, Poland). Geologos 19 (this issue), 95-129.

Mange, M.A. \& Maurer, H.F.W., 1992. Heavy minerals in colour. Chapman and Hall, London, $147 \mathrm{pp}$.

Mange, M.A. \& Morton, A.C., 2007. Geochemistry of heavy minerals. [In:] M. Mange \& D.T. Wright (Eds): Heavy minerals in use. Developments in Sedimentology 58, 345-391.

Mange, M., Turner, P., Ince, D., Pugh, J. \& Wright, D., 1999. A new perspective on the zonation and correlation of barren strata: an integrated heavy mineral and palaeomagnetic study of the Sherwood Sandstone Group, East Irish Sea Basin and surrounding areas. Journal of Petroleum Geology 22, 325-348.

Marcinkowski, B. \& Mycielska-Dowgiałło, E., 2013. Heavy-mineral analysis in Polish investigations of Quaternary deposits: a review. Geologos 19 (this issue), 5-23.

Mattinson, J.M., 2010. Analysis of the relative decay constants of $235 \mathrm{U}$ and $238 \mathrm{U}$ by multi-step CA-TIMS 
measurements of closed-system natural zircon samples. Chemical Geology 275, 186-198.

McKie, T. \& Williams, B., 2009. Triassic palaeogeography and fluvial dispersal across the northwest European Basins. Geological Journal 44, 711-741.

McKie, T., Aggett, J. \& Hogg, A.J.C., 1998. Reservoir architecture of the upper Sherwood Sandstone, Wytch Farm field, southern England. [In:] J.R. Underhill (Ed.): Development, evolution and petroleum geology of the Wessex basin. Geological Society, London, Special Publications 133, 133-406.

Miller, B.V., Samson, S.D. \& D'Lemos, R.S., 2001. U-Pb geochronological constraints on the timing of plutonism, volcanism, and sedimentation, Jersey, Channel Islands, UK. Journal of the Geological Society (London) $158,243-252$.

Morton, A.C., 2012. Value of heavy minerals in sediments and sedimentary rocks for provenance, transport history and stratigraphic correlation. [In:] P. Sylvester (Ed.): Quantitative mineralogy and microanalysis of sediments and sedimentary rocks. Mineralogical Association of Canada Short Course Series 42, 133-165.

Morton, A.C. \& Hallsworth, C.R., 1994. Identifying provenance-specific features of detrital heavy mineral assemblages in sandstones. Sedimentary Geology 90, 241-256.

Morton, A.C., Fanning, C.M. \& Jones, N.S., 2010. Variscan sourcing of Westphalian (Pennsylvanian) sandstones in the Canonbie Coalfield, UK. Geological Magazine $147,718-727$.

Nasdala, L., Hofmeister, W., Norberg, N., Mattinson, J.M., Corfu, F., Dörr, W., Kamo, S.L., Kennedy, A.K., Kronz, A., Reiners, P.W., Frei, D., Košler, J., Wan, Y., Götze, J., Häger, T., Kröner, A. \& Valley, J.W., 2008. Zircon M257 - a homogeneous natural reference material for the ion microprobe U-Pb analysis of zircon. Geostandards and Geoanalytical Research 32, 247-265.

Preto, N., Kustatscherc, E. \& Wignall, P.B., 2010. Triassic climates - state of the art and perspectives. Palaeogeography, Palaeoclimatology, Palaeoecology 290, 1-10.

Purvis, K. \& Wright, V.P., 1991. Calcretes related to phreatophytic vegetation from the Middle Triassic Otter Sandstone of southwestern England. Sedimentology 38, 539-551.

Roach, R.A., Lees, G.J. \& Shufflebotham, M.M., 1990. Brioverian volcanism and Cadomian tectonics, Baie de St Brieuc, Brittany: stages in the evolution of a late Precambrian ensialic basin. [In:] R.S. D'Lemos, R.A. Strachan \& C.C. Topley (Eds): The Cadomian orogeny. Geological Society, London, Special Publications 51, 41-67.

Ruffell, A. \& Shelton, R., 1999. The control of sedimentary facies by climate during phases of crustal extension; examples from the Triassic of onshore and offshore England and Northern Ireland. Journal of the Geological Society 156, 779-789.

Samson, S.D. \& D'Lemos, R.S., 1998. U-Pb geochronology and Sm-Nd isotopic composition of Proterozoic gneisses, Channel Islands, UK. Journal of the Geological Society 155, 609-618.
Samson, S.D., D’Lemos, R.S., Miller, B.V. \& Hamilton, M.A., 2005. Neoproterozoic palaeogeography of the Cadomia and Avalon terranes: constraints from detrital zircon U-Pb ages. Journal of the Geological Society $162,65-71$.

Schulmann, K., Schaltegger, U., Jezek, J., Thompson, A.B. \& Edel, J.-B., 2002. Rapid burial and exhumation during orogeny: thickening and synconvergent exhumation of thermally-weakened and thinned crust (Variscan orogen in western Europe). American Journal of Science 302, 856-879.

Sircombe, K.N., 2004. AgeDisplay: an EXCEL workbook to evaluate and display univariate geochronological data using binned frequency histograms and probability density distributions. Computers $\mathcal{E}$ Geosciences 30, 21-31.

Sláma, J., Košler, J., Condon, D.J., Crowley, J.L., Gerdes, A., Hanchar, J.M., Horstwood, M.S.A., Morris, G.A., Nasdala, L., Norberg, N., Schaltegger, U., Schoene, B., Tubrett, M.N. \& Whitehouse, M.J., 2008. Plešovice zircon - a new natural reference material for $\mathrm{U}-\mathrm{Pb}$ and Hf isotopic microanalysis. Chemical Geology 249, 1-35.

Smith, S.A., 1990. The sedimentology and accretionary styles of an ancient gravel-bed stream: the Budleigh Salterton Pebble Beds (Lower Triassic), southwest England. Sedimentary Geology 67, 199-219.

Smith, S.A. \& Edwards, R.A. 1991. Regional sedimentological variations in Lower Triassic fluvial conglomerates (Budleigh Salterton Pebble Beds), southwest England: some implications for palaeogeography and basin evolution. Geological Journal 26, 65-83.

Stacey, J.S. \& Kramers, J.D., 1975. Approximation of terrestrial lead isotope evolution by a two-stage model. Earth and Planetary Science Letters 26, 207-221.

Steel, R.J. \& Thompson, D.B., 1983. Structures and textures in Triassic braided stream conglomerates ('Bunter' Pebble Beds) in the Sherwood Sandstone Group, North Staffordshire, England. Sedimentology 30, 341-367.

Svendsen, J.B. \& Hartley, N.R., 2001. Comparison between outcrop-spectral gamma ray logging and whole rock geochemistry: implications for quantitative reservoir characterization in continental sequences. Marine and Petroleum Geology 18, 657-670.

Svendsen, J.B. \& Hartley, N.R., 2002. Synthetic heavy mineral stratigraphy: applications and limitations. Marine and Petroleum Geology 19, 389-405.

Thomas, H.H., 1902. Mineralogical constitution of the finer material of the Bunter Pebble-Bed in the west of England. Quarterly Journal of the Geological Society of London 58, 620-632.

Thomas, H.H., 1909. A contribution to the petrography of the New Red Sandstone in the west of England. Quarterly Journal of the Geological Society of London 65, 229-244.

Thompson, D.B., 1970. Sedimentation of the Triassic (Scythian) red pebbly sandstones in the Cheshire Basin and its margins. Geological Journal 7, 183-216.

Tischendorf, G., Förster, H.-J., Frischbutter, A., Kramer, W., Schmidt, W. \& Werner, C.D., 1995. Igneous activity. [In:] R.D. Dallmeyer, W. Franke \& K. Weber 
(Eds): Pre-Permian geology of central and eastern Europe. Springer-Verlag, Berlin, 249-259.

Tyrrell, S., Haughton, P.D.W., Souders, A.K., Daly, J.S. \& Shannon, P.M., 2012. Large-scale, linked drainage systems in the NW European Triassic: insights from the $\mathrm{Pb}$ isotopic composition of detrital K-feldspar. Journal of the Geological Society 169, 279-295.

Van Loon, A.J. \& Mange, M.A., 2007. "In situ” dissolution of heavy minerals through extreme weathering, and the application of the surviving assemblages and their dissolution characteristics to correlation of Dutch and German silver sands. [In:] M.A. Mange \& D.T. Wright (Eds): Heavy minerals in use. Developments in Sedimentology 58, 189-213.

Vidal, P., Auvray, B., Charlot, R. \& Cogné, J., 1981. Precambrian relicts in the Armorican Massif: their age and role in the evolution of the western and central European Cadomian-Hercynian belt. Precambrian Research 14, 1-20.

Warrington, G. \& Ivimey-Cooke, H.C., 1992. Triassic. [In:] J.C.W. Cope, J.K. Ingham \& P.F. Rawson (Eds): Atlas of palaeogeography and lithofacies. Geological Society, London, Memoir 13, 97-106.

Wills, L.J., 1956. Concealed coalfields. Blackie, London, 208 pp.

Wills, L.J., 1970. The Triassic succession in the central Midlands in its regional setting. Quarterly Journal of the Geological Society of London, 126, 225-283.

Woronko, B., Rychel, J., Karasiewicz, M.T., Ber, A., Krzywicki, T., Marks, L. \& Pochocka-Szwarc, K., 2013. Heavy and light minerals as a tool for reconstruction of depositional environments: an example from the Jałówka site (northern Podlasie region, NE Poland). Geologos 19 (this issue), 47-66.

Wright, V.P., Marriott, S.B. \& Vanstone, S.D., 1991. A reg palaeosol from the Lower Triassic of south Devon: stratigraphic and palaeoclimatic implications. Geological Magazine 128, 517-523.

Manuscript received: 30 November 2011 Revision accepted: 22 February 2013 